\title{
Barriers to Innovation: Experience of Ecuadorian Small and Medium Entreprises
}

\author{
Luis Enrique Simbaña-Taipe \\ lesimbania@espe.edu.ec \\ Universidad de las Fuerzas Armadas ESPE, Sangolquí, Ecuador \\ Jimena Alexandra Villamil-Jaramillo \\ jimevillamil20@outlook.es \\ Universidad de las Fuerzas Armadas ESPE, Sangolquí, Ecuador \\ Laura Lucia Taimal-Méndez \\ lalu 03102011@hotmail.com \\ Universidad de las Fuerzas Armadas ESPE, Sangolquí, Ecuador \\ David Rodeiro-Pazos \\ david.rodeiro@usc.es \\ Universidade de Santiago de Compostela, Galicia, Spain
}

\begin{abstract}
The innovation barriers to small and medium-sized enterprises affect their innovative process and influence their company development. In this empirical work, we analyze the cost, market, and knowledge barriers that impede or delay the development of innovative activities and projects in Ecuadorian SMEs. A logit estimation model uses fixed-effects panel data on a sample of 5,205 SMEs during the period from 2009-2014. The results show that small and young companies are more vulnerable to the perceived barriers of cost and knowledge. This is mainly due to high innovation costs and a lack of skilled staff that restricts organizational growth and market competitiveness.
\end{abstract}

Keywords: innovation barriers, SMEs, competitiveness, logit, panel data 


\title{
Barriers to Innovation: Experience of Ecuadorian Small and Medium Entreprises
}

\author{
Luis Enrique SIMBAÑA-TAIPE \\ lesimbania@espe.edu.ec \\ Universidad de las Fuerzas Armadas ESPE, Sangolquí, Ecuador \\ Jimena Alexandra VILLAMIL-JARAMILLO \\ jimevillamil20@outlook.es \\ Universidad de las Fuerzas Armadas ESPE, Sangolquí, Ecuador \\ Laura Lucia TAIMAL-MÉNDEZ \\ lalu 03102011@hotmail.com \\ Universidad de las Fuerzas Armadas ESPE, Sangolquí, Ecuador \\ David Rodeiro-Pazos \\ david.rodeiro@usc.es \\ Universidade de Santiago de Compostela, Galicia, Spain
}

\section{Resumen}

Las barreras a la innovación para las pequeñas y medianas empresas afectan su proceso innovador e influyen en el desarrollo de su empresa. En este trabajo empírico analizamos las barreras de costo, mercado y conocimiento que impiden o retrasan el desarrollo de actividades y proyectos innovadores en las PYMES ecuatorianas. Un modelo de estimación logit utiliza datos de panel de efectos fijos en una muestra de 5205 pymes durante el período 2009-2014. Los resultados muestran que las empresas pequeñas y jóvenes son más vulnerables a las barreras percibidas de costo y conocimiento. Esto se debe principalmente a los altos costos de innovación y la falta de personal calificado que restringe el crecimiento organizacional y la competitividad en el mercado. 


\section{Introduction}

The companies' interest in achieving a competitive advantage leads them to develop processes with greater sustainable global growth. However, innovation continues to be one of the most powerful sources to gain a competitive advantage for a company (Hossain, 2016). A company's innovation is the producing and financing of a product or service $(O E C D, 2018)$ that the company markets and introduces as a new or improved process (EUROSTAT \& Nås, 2011). Therefore, innovation has become a fundamental element in a competitive age when consumers' needs are constantly changing and the product lifecycle is shorter (Das, Verburg, Verbraeck, \& Bonebakker, 2018).

In addition, innovation fosters economic growth and development (Tello, 2014). It supports increased productivity levels, improved exports, and adds value to income and employment levels (Banco Central Europeo, 2017). To improve production efficiency and reduce costs, innovation strategies offer competitive properties in today's market (Türkeș et al., 2019)

In the case of small and medium-sized enterprises (SMEs), innovations are also an important growth factor to gain overall success and economic benefit (Toomsalu, Tolmacheva, Vlasov, \& Chernova, 2019). Moreover, SMEs often face cash crises due to a lack of internal and external financial resources (Gupta \& Barua, 2018).

Innovation barriers are defined as the difficulties when implementing innovative projects. These difficulties hamper, delay, or impede the proper functioning and development of innovative activities (Hartono \& Kusumawardhani, 2019). The research has categorized these barriers into internal and external (Piater, 1984); Seidel-Sterzik, McLaren, and Garnevska, (2018) have also used this approach for SMEs, while D'Este, lammarino, Savona, and von Tunzelmann, (2012) have ranked the barriers as deterring and revealed. This latter approach is used in this study.

The objective of this study is to identify the effects of company and innovation characteristics on the innovation barriers of Ecuadorian SMEs. Regarding the total of Ecuador's companies, $31.4 \%$ are small and $12.5 \%$ are medium-sized (Superintendencia de Compañías, 2015). We use a logistic regression with fixed effects for panel data as our model.

The results of this study provide a significant contribution to the limited literature on innovation barriers of Ecuadorian SMEs. This study is structured as follows: section 2 presents a literature review on innovation barriers and independent variables. Section 3 sets out the data, sample, estimation strategy, and empirical research model. The univariate and multivariate analysis is shown in section 4 . Sections 5 and 6 provide a discussion and conclusions, policy recommendations, limitations, and future lines of research. 


\section{Literature Review}

In this section, we describe the main barriers to innovation by dividing them into three different groups of dependent variables. Second, we review the main determinants of these barriers as our independent variables.

\section{Barriers to Innovation; dependent variables}

Innovation is considered a fundamental tool for the economy and company development because it enables the generation of employment and wealth (Erazo, 2018). It allows organizations to achieve a higher level of sustained competitiveness in the market (Corchuelo and Carvalho, 2013). Zapata et al. (2014) say that innovation is a learning process that creates knowledge and generates capabilities that facilitate a company's optimal use of business resources. The need to develop innovation processes is fundamental for the competitiveness of SMEs (Lesáková, 2014).

Compared to large enterprises, SMEs have certain advantages: flexible company structures and less bureaucratic and administrative constraints to adapt to the market. Furthermore, they use informal and effective internal communication, and they may be more willing to take risks. Despite the above advantages, SMEs also have some disadvantages, as they have limited research and innovation capabilities and frequently face financial problems (Lesáková et al., 2017). Due to financial difficulties, only $14 \%$ of SMEs are involved in innovation in Ecuador (INEC, 2013; Zapata et al., 2014).

According to the literature review, Shumpeter's creative destruction is considered one of the main arguments that explains the innovation process (Figueroa, 2013). This concept focuses on eliminating old business models and creating new products and industries. SMEs should be careful in shaping their management practices, organizational structures, and the use of technology according to their competitive environment, as they have significant effects on building their innovative capacity (Mclaughlin, 2011).

Additionally, Figueroa (2013) states that in order to achieve creative destruction, companies' should create, apply, and transmit innovation; while De la Corte (2015) points out that innovation is related to new combinations and acts of creative destruction as developed by the innovative entrepreneur. This type of leader is responsible for new and dynamic production processes by stimulating a company's innovation and investment (Gonzáles, 2017). However, this process is affected by innovation barriers that hinder the growth and development of organizations. For this reason, it is essential to identify the explanatory variables that reduce or eliminate these barriers.

Piater (1984) states that the barriers are elements that negatively affect innovation activities and can be internal and external. Internal innovation barriers relate to the lack of internal funds, high innovation costs, and lack of qualified personnel (Segarra, et al., 2008). External obstacles refer to the difficulty in obtaining technological information, the lack of external funds, and the lack of communication and specific policies (Hadjimanolis, 1999). Insufficient company investments to finance improvements in products and services affect the innovation performance of SMEs (D'Este, Rentocchini, \& VegaJurado, 2014). Therefore, analyzing the internal and external conditions offers a 
comprehensive view of the problem (Xiaobao, Wei, \& Yuzhen, 2013; Božić \& Rajh, 2016).

Likewise, D'Este, lammarino, Savona, and von Tunzelmann, (2012) categorize barriers as deterring and revealed. On the one hand, the first obstacles are considered insuperable, because the high probability of dissolution of innovation projects (Pellegrino, 2018). On the other hand, the revealed ones refer to the difficulties that arise after some innovative process (Corchuelo \& Mesías, 2015).

Considering the previous review and the information from the innovation activities surveys of the National Institute of Statistics and Census (INEC) to Ecuadorian SMEs 2009- 2014; this study focuses on three barrier groups (cost, market, and knowledge). Cost barriers are those that reflect the knowledge of the availability of the economic resources to invest in innovation projects (Segarra et al., 2008). The behavior of companies facing cost barriers is attributable to the high cost and risk of innovation (Kuppig et al., 2016; Heredia Pérez, Geldes, Kunc, \& Flores, 2019). These types of barriers can be classified as a lack of internal financing, lack of external financing, and high costs of innovation (Segarra et al., 2008; Morales, 2012; Corchuelo \& Mesías, 2015 and Pellegrino, 2018).

Market barriers reflect the understanding of the market performance of the company. They concentrate on the market structure and the demand for goods and services (Alfaro and Caneo, 2014). These strategies focus on consolidating in existing markets, opening in new markets, and improving the level of customer satisfaction. Consequently, if there are market barriers, they directly impact the performance of the company (Pino, Felzensztein, Zwerg-Villegas, \& Arias-Bolzmann, 2016). SMEs are susceptible to such obstacles, because they have little experience in the market (García y López, 2010).

Knowledge barriers regard the company's understanding of whether it possesses the appropriate information or can easily retain such knowledge. This type of obstacle mainly affects the SMEs as the lack of high-potential staff skills (Zamora and Villamar, 2011). Not having updated information is often costly and can cause company development to lag (How et al., 2019). In order to understand the information capacity of Ecuadorian SMEs, we have identified the following knowledge barriers: lack of qualified personnel, lack of information about technology, lack of market information, and difficulties in finding partners for innovation (lammarino et al., 2009; Hock and Messiah, 2015; Monsalvez, 2017; Pellegrino, 2018).

Determinants of barriers to innovation: independent variables

The determinants of innovation barriers are generally related to company characteristics such as age, size, sector, competitive environment, business groups (Pellegrino, 2018), and innovative activity (activities in R\&D, technology intensity or financial support, etc.) (Segarra et al., 2008). This study emphasizes the variables related to company characteristics (size, age, and business group) and innovative activities (R\&D expenses, patents, and organizational innovation).

Size: Company size is an elementary factor in achieving scale economies. Aguilar and Fong (2014) argue that size is an element that influences the innovative behavior of 
companies (CEPAL, 2016). Small companies have greater flexibility, versatility, and ability to adapt to environments, so size can seriously affect the innovation process (LealRodríguez, Eldridge, Roldán, Leal-Millán \& Ortega-Gutiérrez, 2015). García y López (2010) examined a sample of 8,300 Spanish manufacturing companies from 2005-2007; they established a positive size ratio over market barriers. Additionally, Aguilar and Fong (2014) analyzed a sample of 221 Mexican companies during 2009; they determined that small businesses were more sensitive to cost barriers. Coad et al. (2016) studied a sample of 28,000 UK companies from 2002 to 2010; they established a positive effect between small businesses and barriers of cost, knowledge, and market innovation. This result aligns with Monsalvez (2017) who reviewed 230 SMEs in Chile from 2013 to 2014 and argued that small businesses were more susceptible to cost and knowledge barriers due to their lack of financial resources and cooperation from investors. Considering these results, which show a positive effect of size on innovation barriers (Aguilar and Fong, 2014; Coad et al., 2016; Monsalvez, 2017), the following hypothesis is established:

$\mathbf{H}_{\mathbf{1}}:$ : Ecuadorian small businesses are more sensitive to cost and knowledge barriers.

Age: Company age is defined as the number of years since a company's creation. Moreover, it is a fundamental research factor to determine the actual capacity for innovation and the effects of its barriers (Pinget, Bocquet, \& Mothe, 2015). The study of Coad, Holm, Krafft, and Quatraro (2018) indicates that this variable can influence a company's profit and performance. Morales (2012) analyzed a sample of 40,523 Spanish service companies during the period from 2003-2009 and determined that young companies were more sensitive to cost barriers. This result is similar to Corchuelo y Mesías (2015) who explored a sample of 204 Spanish manufacturing companies in 2013 and found that young exporting companies were more susceptible to cost and market barriers, mainly due to the lack of financial resources. Pellegrino (2018) examined a sample of 96,000 Spanish companies in the manufacturing and services sectors for the period from 2004-2011. He argued that young companies (1-20 years) were more susceptible to cost and knowledge barriers, while mature companies ( $21>51$ years) did not face such obstacles. The literature has found evidence of a positive effect (Morales, 2012; Hock and Messiah, 2015; Pellegrino, 2018), and therefore the following hypothesis is raised:

$\mathbf{H}_{2}$ : Young Ecuadorian SMEs are more sensitive to cost barriers.

Business Group: A business group is the collection of independent companies with the purpose of diversifying their operations and generating greater profitability through collaboration in financial, operational, administrative, and innovation processes (Balarezo and Ortega, 2018). This collaboration supports the transfer of technology, knowledge, and innovation. Furthermore, SMEs within a business group can develop corporate culture and partnerships (Strobel \& Kratzer, 2016). D'Este et al. (2012) did a survey of 16,445 UK companies in the manufacturing and services sectors in 2005 . They found that companies in a non-economic group were susceptible to financial obstacles. This result aligns with Monsalvez (2017) who studied 230 Chilean SMEs from 20132014. Similarly, Pellegrino (2018) examined a sample of 96,000 Spanish companies in the manufacturing sector from 2004-2011. Based on this negative relationship of a 
business group with innovation barriers (D'Este et al., 2012; Monsalvez, 2017; Pellegrino, 2018), the following hypothesis is established:

$\mathbf{H}_{3}$ : Ecuadorian SMEs belonging to a business group are not susceptible to cost and knowledge barriers.

R\&D Expenses: Research and development are aligned to discover new scientific or technical knowledge. For this reason, investment in R\&D must be incorporated as an innovation strategy (Olaya, 2018). Furthermore, CEPAL (2016) states that R\&D expenditures are a factor that determines the technological and innovative effort of organizations. Segarra et al. (2008) analyzed the data from 2,954 Spanish companies in manufacturing and services from 2002-2004. They argued that companies participating in R\&D are more likely to perceive obstacles of cost and knowledge. In addition, García y López (2010) examined a sample of 8,300 manufacturing companies in Spain from 2005-2007; they established that companies that invested in R\&D are more sensitive to cost and market barriers. Zhu et al. (2012) studied a sample of 41 Chinese SMEs in the service sector in 2009; they stated that companies that use their resources in innovation and development are susceptible to cost barriers. This result is mainly caused by a lack of support from financial institutions. Innovation financing remains a key challenge for SMEs, especially in developing economies (Pachouri \& Sharma, 2016). Considering the positive impact of innovation and development expenditure on innovation barriers (Segarra et al., 2008; García y López, 2010; Zhu et al., 2012; Božić \& Rajh, 2016); the following hypothesis is raised:

$\mathbf{H}_{4}$ : Ecuadorian SMEs that invest in R\&D are more sensitive to the perceived barriers of cost, knowledge, and market.

Patents: Patents are a property title granted to the inventor to protect an invention (Ecuadorian Institute of Industrial Property, 2016). Moreover, patents are considered as a significant indicator of innovation and their registration investment is shown as company growth (Yu, Yan, \& Assimakopoulos, 2015). It is important to emphasis that this variable is fundamental for innovation, so several authors use it to determine its effect on innovation barriers. Zhu et al. (2012) studied a sample of 41 Chinese SMEs in the services sector in 2009; they determined that companies that patent their inventions are more likely to perceive financial obstacles. This result aligns with Portillo et al. (2015) who examined a sample of 883 Spanish companies in the manufacturing sector from 2010-2013; they pointed out that patent-registering companies were sensitive to cost barriers. This study is in line with what was found by Pellegrino (2018) who analyzed a total sample of 96,000 Spanish companies in the manufacturing and service sectors from 2004-2011. According to the above mentioned, the literature review shows a positive effect of patents on innovation barriers (Zhu et al., 2012; Portillo et al., 2015; Pellegrino, 2018), so the following hypothesis is formulated:

$\mathbf{H}_{5}$ : The Ecuadorian SMEs with patents are more susceptible to cost and knowledge barriers.

Organizational Innovation: Organizational innovation refers to the implementation of new organizational practices and procedures that are related to knowledge management, 
production and supply operations, quality, workplace modification, and external relations of the company (OECD, 2018).

Table 1 has a summary of our dependent and independent variables.

Table 1. Description of dependent and independent variables

\begin{tabular}{|c|c|c|c|c|}
\hline $\begin{array}{c}\text { Type of } \\
\text { variables }\end{array}$ & Group & Factor & Description & Definition \\
\hline \multirow{9}{*}{$\begin{array}{l}\text { Dependent } \\
\text { Variables }\end{array}$} & \multirow{3}{*}{ Cost Barriers } & Barr1 & Lack of internal funding. & \multirow{9}{*}{$\begin{array}{l}\text { One if the company } \\
\text { registers as highly } \\
\text { significant the obstacle } \\
\text { to innovation and zero } \\
\text { for all other }\end{array}$} \\
\hline & & Barr2 & Lack of external funding & \\
\hline & & Barr3 & High costs of innovation. & \\
\hline & \multirow[t]{3}{*}{ Market Barriers } & Barr4 & $\begin{array}{l}\text { Demand uncertainty } \\
\text { innovative } \\
\text { soor } \\
\text { services. }\end{array}$ & \\
\hline & & Barr5 & $\begin{array}{l}\text { Market dominated by } \\
\text { established companies. }\end{array}$ & \\
\hline & & Barr6 & $\begin{array}{l}\text { Lack of qualified personnel } \\
\text { in the company. }\end{array}$ & \\
\hline & \multirow{3}{*}{$\begin{array}{l}\text { Knowledge } \\
\text { Barriers }\end{array}$} & Barr7 & $\begin{array}{l}\text { Lack of information about } \\
\text { technology }\end{array}$ & \\
\hline & & Barr8 & Lack of market information. & \\
\hline & & Barr9 & $\begin{array}{l}\text { Difficulty } \\
\text { cooperation partners for } \\
\text { innovation. }\end{array}$ & \\
\hline \multirow{6}{*}{$\begin{array}{l}\text { Independent } \\
\text { Variables }\end{array}$} & \multirow{3}{*}{$\begin{array}{l}\text { Company } \\
\text { Characteristics }\end{array}$} & Size & Size & $\begin{array}{l}\text { One if the company is } \\
\text { small and zero if medium }\end{array}$ \\
\hline & & Age & Age & $\begin{array}{l}\text { One if the company is } \\
\text { young (under } 20 \text { years) } \\
\text { and zero if mature (older } \\
\text { than } 20 \text { years). }\end{array}$ \\
\hline & & Grep & Business Group & $\begin{array}{l}\text { One if the company } \\
\text { belongs to a business } \\
\text { group and zero } \\
\text { otherwise. }\end{array}$ \\
\hline & \multirow{3}{*}{$\begin{array}{l}\text { Innovation } \\
\text { Characteristics }\end{array}$} & Gii & Internal R\&D expenses & $\begin{array}{l}\text { One if the company } \\
\text { registers an internal } \\
\text { R\&D expense item and } \\
\text { zero otherwise. }\end{array}$ \\
\hline & & Pat & Patents & $\begin{array}{l}\text { One if the company has } \\
\text { patents and zero } \\
\text { otherwise }\end{array}$ \\
\hline & & Innor & Organizational innovation & $\begin{array}{l}\text { One if the company } \\
\text { applies organizational } \\
\text { innovation and zero } \\
\text { otherwise }\end{array}$ \\
\hline
\end{tabular}

Note: all variables are represented as a binary variable or dummy.

Furthermore, Udagedara and Allman (2017) indicate that organizational innovation improves the efficiency and productivity of a company's business practices. Camargo (2008) studied a sample of 200 manufacturing companies in Colombia in 2007; he 
determined that companies that develop organizational innovation have a greater cost hurdle that is mainly due to low availability of financial resources. Meanwhile, Coad et al. (2016) studied a sample of 28,000 UK companies in the manufacturing sector from 20022010; they determined that SMEs investing in organizational innovation are more likely to perceive cost and knowledge barriers.

This result aligns with that of Silvestre y Rodríguez (2018) who analyzed a sample of 8,056 Colombian companies in the commercial and service sector during 2014-2015.

This is also consistent with Hartono and Kusumawardhani (2019) who revised 1,500 Indonesian manufacturing companies during the period from 2009-2010; they stated that the companies that introduced organizational innovation were susceptible to perceived financial and knowledge barriers. So, a positive relationship between organizational innovation and innovation barriers was evident (Coad et al., 2016; Silvestre \& Rodriguez, 2018; Hartono and Kusumawardhani, 2019). Therefore, the following hypothesis is formulated:

$\mathbf{H}_{\mathbf{6}}$ : Ecuadorian SMEs that develop organizational innovation are sensitive to cost and knowledge barriers.

\section{Sample and Methodology}

Data

This study is based on the information of INEC national survey of innovation activities (9,090 Ecuadorian companies). It covers the four economic sectors of the International Uniform Industrial Classification (ISIC) from the Oslo Handbook (OECD, 2018) for the period from 2009-2014. A process of information debugging was carried out to obtain a homogeneous and relevant sample. The debugging process considered several criteria for SMEs. First, 3,470 companies classified as large were eliminated. Second, 415 companies were excluded because they record information for only one year. A final sample of 5,205 SMEs was obtained that generated a total of 16,644 observations.

Strategy of estimation and model specification

On the one hand, the INEC database structure is composed of cross-sectional observations for the period from 2009-2014. For this reason, this study uses the technique of panel data, as this method can combine two types of data: structural and temporal (Mayorga and Muñoz, 2000). On the other hand, to establish the relationship between company characteristics and innovation with innovation barriers, we use a logit binary model. It can be estimated by means of panel data and fixed or random effects. However, in order to choose the most suitable model, the Hausman test is performed to determine the consistency of the estimators and the relevance of the variables. The results established that the logit model with fixed effects panel data was the most suitable. This model was specifically used to relate a group of independent variables with a non-metric dependent variable by assigning two types of responses: zero (failure, absence) or one (success, presence) (Ucedo, 2013). Therefore, innovation barriers ( $\left.Y_{i}\right)$ 
were assigned the value of one if they were considered as highly important by companies or zero otherwise.

$$
\begin{array}{r}
Y_{i} 1 \text { if } Y_{i}^{*}>0 \\
0 \text { if } Y_{i}^{*}<0
\end{array}
$$

lammarino et al. (2009), Corchuelo and Mesías (2015), Díaz et al. (2016), and Coad et al. (2016) use the binary logit model in their research with the following expression:

$$
Y_{i t}=\beta_{t} X_{i t}+\alpha_{i}+\mu_{i t}
$$

where $Y_{i t}$ is the dependent variable ( $i=$ entity and $t=$ time), $\beta_{t}$ is the vector of the coefficients to be estimated, $X_{i t}$ represents the independent variables, $\alpha_{i}(1 \ldots n)$ is the unknown intercept for each company, and $\mu$ it is the error term. The model, in empirical contrast, measures the effect or susceptibility that the independent variables generate for the Ecuadorian SMEs' innovation barriers. This model fits the one used by Pellegrino (2018) and Silvestre and Rodriguez (2018) who consider the following equation:

$$
Y_{i t}=\beta_{t} X_{i t}+c_{i}+\varepsilon_{i t}>0
$$

Where $Y_{i t}$ represents the binary dependent variables, $\beta_{t}$ represents the vector of the independent variables, $X_{i t}$ is the set of independent variables, $c_{i}$ is the individual invariant effect in unobserved time, and $\varepsilon_{i t}$ is the error term.

\section{Results}

Univariate analysis

Table 2 shows the median of the sample; it is related to the importance of specific companies' innovation barriers. The most significant barrier is high innovation costs at $79 \%$. Within market barriers, uncertain demand for goods or services dominates at $60 \%$. And in relation to knowledge barriers, the lack of information about technology is a highlight at $55 \%$.

The descriptive statistics show that $84.42 \%$ of companies are small due to size; the average SMEs age is 15.51 years old, and the average number of employees (emp) is 32. Only $8.97 \%$ of SMEs belong to a business group (grep), $8.96 \%$ record internal R\&D expenses (gii), $8.97 \%$ have patents (pat), and $25.51 \%$ invest in organizational innovation (innor). These last three innovation variables show that there is little innovation activity in Ecuadorian SMEs. 
Table 2. Proportion of companies that consider innovation barriers to be highly important

\begin{tabular}{lll}
\hline \multicolumn{1}{c}{ Innovation Barriers } & \multicolumn{1}{c}{ Description } & Median \\
\hline \multirow{2}{*}{ Cost Barriers } & Lack of internal funding. & 0.7118 \\
& Lack of external funding. & 0.5420 \\
& High costs of innovation. & 0.7918 \\
& & 0.6035 \\
Market Barriers & Uncertain Demand for innovative goods or services. & 0.5988 \\
& Market dominated by established companies. & 0.5440 \\
Knowledge Barriers & & 0.5478 \\
& Lack of qualified personnel in the company. & 0.5153 \\
\hline & Lack of information about technology & 0.3925 \\
\hline
\end{tabular}

Note: Companies can determine how highly important one or more innovation barriers are.

\section{Multivariate analysis}

The results of the multivariate analysis are presented in Table 3. The company size has a positive relationship over cost barriers (lack of financing from external sources and very high innovation costs) that means small companies are more sensitive to these obstacles. Likewise, the size shows a positive relationship with knowledge barriers (lack of qualified personnel in the company and lack of market information); this relationship indicates that small companies are susceptible to such barriers. It may be caused by a lack of qualified staff in Ecuadorian SMEs, as argued by Ramírez and Sebastian (2015). Knowledge barriers can lead to a reduction in the competition level. These results support hypothesis 1, and they align with those obtained by García y López (2010), Coad et al. (2016), and Monzalves (2017).

Regarding the age variable, it has a positive relationship with innovation costs that indicates young companies are more sensitive to this type of obstacle. Meanwhile, mature companies provide more confidence to banking institutions that thus, enables them to raise more capital to finance and meet the costs of innovation activities. Moreover, this variable influences the company's activities, probably due to the link to organizational reputation (Coad et al., 2018). This result is aligned to data of the Central Bank of Ecuador (2016) that states that the credit volume share of SMEs is $4.7 \%$ of the total of 15 analyzed segments. This finding supports hypothesis 2 and verifies the results obtained by Morales (2012), Corchuelo y Mesías (2015); Pellegrino (2018). Age has a negative relationship with the lack of market information that means young companies 
are not sensitive to this obstacle. This result is probably caused by the flexibility of young companies to adapt to market needs (Lesáková et al., 2017).

The business group (grep) variable has a significantly negative effect on the barriers of a lack of technology information and difficulty in finding partners for innovation. These barriers mean that SMEs that belong to a business group are not susceptible to these knowledge barriers. However, belonging to an economic group can improve the organization's limitations by covering greater market exposure and increasing its profitability (Monsalvez, 2017). However, in Ecuador only 9\% of SMEs belong to economic groups. This result supports hypothesis 3 and aligns with those obtained by Morales (2012), D'Este et al. (2012), Monsalvez (2017), and Pellegrino (2018).

The internal variable R\&D expense (gii) shows a positive relationship with the barriers of cost, market, and knowledge. This relationship means that SMEs that have this type of innovation activity are more sensitive to these obstacles. Companies that invest in R\&D must bear high costs and have qualified staff. In Ecuador according to INEC data (2014), only $16.69 \%$ of companies invest in R\&D that is mainly due to a lack of economic resources and information. These results make it possible to accept hypothesis 4 , and they align with the findings obtained by Segarra (2008), Tiwari and Buse (2007), García y López (2010), and Zhu et al. (2012).

The patent variable (pat) has a positive effect on cost barriers (lack of funds within the organization and very high innovation costs), market obstacles (uncertain demand for innovative goods or services), and knowledge complications (lack of qualified personnel within the company, lack of market information, and difficulty finding partners for innovation). Small and medium-sized enterprises that register patents are sensitive to these barriers. In Ecuador, that procedure has high costs and must meet rigid requirements (inventive level, novelty, and industrial application) (El Comercio, 2016). These results support hypothesis 5 and the findings obtained by Zhu et al. (2012), Portillo et al. (2015), and Pellegrino (2018).

Finally, the organizational innovation variable (innor) has a positive relationship with the barriers of cost, market, and knowledge, especially for SMEs. On the other hand, only $9 \%$ of Ecuadorian SMEs implement this kind of strategy. For this reason, this group of companies presents difficulties in their growth and development activities. These results support hypothesis 6 , and they are partially in line with those obtained by Camargo (2008), Coad et al. (2016), Silvestre y Rodríguez (2018), and Hartono and Kusumawardhani (2019).

Moreover, Table 3 shows the value of the LR Chi-square. This statistical value indicates whether or not two or more qualitative variables are associated. The results show that there is a significant relationship between the independent and dependent variables, as their value is between 45.96 and 100.30 (high). 
Table 3. Logit Model with fixed effects panel data

\begin{tabular}{|c|c|c|c|c|c|c|c|c|c|}
\hline \multirow[t]{2}{*}{ 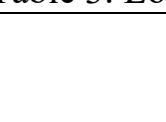 } & \multicolumn{3}{|c|}{ Cost Barriers } & \multicolumn{2}{|c|}{ Market Barriers } & \multicolumn{4}{|c|}{ Knowledge Barriers } \\
\hline & barr1 & barr2 & barr3 & barr4 & barr5 & barr6 & barr7 & barr8 & barr9 \\
\hline $\begin{array}{c}\text { Variabl } \\
\text { es }\end{array}$ & $\begin{array}{c}\text { Lack } \\
\text { of } \\
\text { funds } \\
\text { within } \\
\text { your } \\
\text { comp } \\
\text { any } \\
\text { or } \\
\text { group } \\
\text { for } \\
\text { innov. } \\
\text { activit } \\
\text { ies }\end{array}$ & $\begin{array}{l}\text { Lack } \\
\text { of } \\
\text { funds } \\
\text { from } \\
\text { sourc } \\
\text { es } \\
\text { outsid } \\
\text { e the } \\
\text { comp } \\
\text { any } \\
\text { for } \\
\text { innov. } \\
\text { activit } \\
\text { ies }\end{array}$ & $\begin{array}{c}\text { Very } \\
\text { high } \\
\text { innov. } \\
\text { costs }\end{array}$ & $\begin{array}{c}\text { Market } \\
\text { domin } \\
\text { ated } \\
\text { by } \\
\text { establi } \\
\text { shed } \\
\text { compa } \\
\text { nies }\end{array}$ & $\begin{array}{l}\text { Uncer } \\
\text { tain } \\
\text { dema } \\
\text { nd for } \\
\text { innov. } \\
\text { good } \\
\text { s or } \\
\text { servic } \\
\text { es }\end{array}$ & $\begin{array}{l}\text { Lack } \\
\text { of } \\
\text { qualifi } \\
\text { ed } \\
\text { staff } \\
\text { in the } \\
\text { comp } \\
\text { any } \\
\text { for } \\
\text { innov. } \\
\text { activit } \\
\text { ies }\end{array}$ & $\begin{array}{c}\text { Lack } \\
\text { of } \\
\text { inform } \\
\text { ation } \\
\text { about } \\
\text { techno } \\
\text { logy }\end{array}$ & $\begin{array}{c}\text { Lack } \\
\text { of } \\
\text { mark } \\
\text { et } \\
\text { infor } \\
\text { m. }\end{array}$ & $\begin{array}{c}\text { Difficu } \\
\text { Ity } \\
\text { findin } \\
g \\
\text { partne } \\
\text { rs for } \\
\text { innov } \\
\text { ation }\end{array}$ \\
\hline & 0,075 & 0,801 & 0,744 & & 0,085 & 1,190 & & 0,920 & 0,604 \\
\hline Size & 6 & $9^{*}$ & $3^{*}$ & 0,3254 & 4 & $4^{* *}$ & 0,5967 & $8^{\star *}$ & 4 \\
\hline Age & $\begin{array}{c}0,651 \\
6\end{array}$ & $\begin{array}{c}0,378 \\
2\end{array}$ & $\begin{array}{c}0,872 \\
6^{*}\end{array}$ & $\begin{array}{c}- \\
0,2959\end{array}$ & $\begin{array}{c}- \\
0,130 \\
4\end{array}$ & $\begin{array}{c}- \\
0,334 \\
8\end{array}$ & $\begin{array}{c}- \\
0,7415\end{array}$ & $\frac{-}{1,033}$ & $\begin{array}{c}0,203 \\
8\end{array}$ \\
\hline Grep & $\begin{array}{c}0,621 \\
4\end{array}$ & $\begin{array}{c}0,341 \\
7\end{array}$ & $\begin{array}{c}0,393 \\
2\end{array}$ & $\begin{array}{c}- \\
0,1459\end{array}$ & $\begin{array}{c}- \\
0,151 \\
3\end{array}$ & $\begin{array}{c}- \\
0,304 \\
8\end{array}$ & $\underset{* *}{-}$ & $\begin{array}{c}- \\
0,438 \\
3\end{array}$ & $\begin{array}{c}- \\
1,413 \\
9^{\star *}\end{array}$ \\
\hline Gii & $\begin{array}{c}1,115 \\
4^{* * *}\end{array}$ & $\begin{array}{c}0,616 \\
2^{*}\end{array}$ & $\begin{array}{c}1,393 \\
2^{* * *}\end{array}$ & $\underset{* * *}{1,3969}$ & $\begin{array}{c}1,303 \\
6^{* * *}\end{array}$ & $\begin{array}{c}1,139 \\
6^{* * *}\end{array}$ & $\underset{* * *}{1,4635}$ & $\begin{array}{c}1,656 \\
3^{* * *}\end{array}$ & $\begin{array}{c}1,046 \\
1^{* * *}\end{array}$ \\
\hline Pat & $\begin{array}{c}1,078 \\
3^{* *}\end{array}$ & $\begin{array}{c}0,193 \\
9\end{array}$ & $\begin{array}{c}1,012 \\
4^{* * *}\end{array}$ & $\begin{array}{c}- \\
0,7067 \\
3\end{array}$ & $\begin{array}{c}0,914 \\
0^{* *}\end{array}$ & $\begin{array}{c}0,573 \\
6^{*}\end{array}$ & 0,3427 & $\begin{array}{c}0,636 \\
3^{*}\end{array}$ & $\begin{array}{c}0,854 \\
5^{\star *}\end{array}$ \\
\hline Innor & $\begin{array}{c}1,246 \\
0^{* * *}\end{array}$ & $\begin{array}{c}1,134 \\
3^{* * *}\end{array}$ & $\begin{array}{c}0,738 \\
1^{* * *}\end{array}$ & $\underset{*}{0,4380}$ & $\begin{array}{c}1,018 \\
0^{* * *}\end{array}$ & $\begin{array}{c}0,858 \\
1^{* * *}\end{array}$ & 0,3931 & $\begin{array}{c}0,408 \\
0^{*}\end{array}$ & $\begin{array}{c}0,216 \\
2\end{array}$ \\
\hline $\begin{array}{l}\text { LR chi } \\
\text { square }\end{array}$ & $\begin{array}{c}100,3 \\
00\end{array}$ & $\begin{array}{c}54,27 \\
0\end{array}$ & $\begin{array}{c}92,95 \\
0\end{array}$ & 53,920 & $\begin{array}{c}84,94 \\
0\end{array}$ & $\begin{array}{c}69,04 \\
0\end{array}$ & 72,010 & $\begin{array}{c}89,77 \\
0\end{array}$ & $\begin{array}{c}45,96 \\
0\end{array}$ \\
\hline $\begin{array}{l}\text { Pseudo } \\
\text { R2 }\end{array}$ & $\begin{array}{c}0,106 \\
4\end{array}$ & $\begin{array}{c}0,058 \\
1\end{array}$ & $\begin{array}{c}0,090 \\
6\end{array}$ & 0,0590 & $\begin{array}{c}0,091 \\
2\end{array}$ & $\begin{array}{c}0,072 \\
9\end{array}$ & 0,0757 & $\begin{array}{c}0,088 \\
7\end{array}$ & $\begin{array}{c}0,059 \\
3\end{array}$ \\
\hline $\begin{array}{l}\text { McFad } \\
\text { den's } \\
\text { Adj R2 }\end{array}$ & 0,094 & 0,045 & 0,079 & 0,046 & 0,078 & 0,060 & 0,063 & 0,077 & 0,044 \\
\hline $\mathrm{N} \mathrm{r2}$ & 947 & 939 & 1030 & 918 & 935 & 952 & 955 & 1015 & 779 \\
\hline
\end{tabular}




\section{Discussion}

In this study, we analyze the effect of a number of independent variables related to company characteristics (size, age, and business group) and innovation (internal R\&D expenses, organizational innovation, and patents) on barriers to innovation for Ecuadorian small and medium-sized enterprises. These obstacles affect their innovative process and influence their company development. For this purpose, we used a logistic regression with fixed effects panel data for a sample of 5,205 SMEs, that generated 16,644 observations. The sample of companies belong to four sectors of the economy (mining and quarrying, manufacturing industries, trade, and services) for the period from 2009-2014.

The results show that size is highly susceptible to cost and knowledge barriers. Public financing policies need to be developed to stimulate small company growth. This strategy would improve their cash flow and increase their capacity to face innovation barriers and consequently improve their competitiveness. It is also evident that deficiencies in the education level of Ecuadorian human talent affect SMEs. Therefore, it is necessary to implement education programs that are aimed at improving the skills of staff through constant training. This recommendation may increase the likelihood of successful innovations.

Similarly, the findings confirm that young SMEs (under the age of 20) are sensitive to cost barriers that is mainly due to a lack of internal and external financial resources. There is a priority of developing public policies to provide financial support to young companies so they can face the innovation, production, and marketing project costs. The financial aid should be at preferential rates and come with financial education programs for SMEs. Additionally, young companies are less sensitive to the barrier of a lack of market information. The reason is the flexibility of such companies to adapt to changing market needs.

This study confirms that SMEs that belong to a business group are not susceptible to knowledge barriers. Economic groups improve deficiencies, accumulate market coverage, regulate risks, and increase profitability (Monsalvez, 2017). In Ecuador, these groups have generated a $20.9 \%$ increase in GDP revenue for the period from 2006 to 2015. However, only $0.6 \%$ of SMEs are part of an economic group out of the 215 existing ones (SRI, 2015). Therefore, government and private sector enterprises must jointly generate integration programs to stimulate the partnership of small and medium-sized enterprises with these conglomerates.

Regarding R\&D, companies are clearly more sensitive to innovation barriers. In Ecuador, only $16.69 \%$ of the total INEC (2014) registered companies perform R\&D. The high investing costs and the lack of knowledge of the staff limit innovation activities. Therefore, the government, companies, and educational institutions should generate an economic and knowledge support plan in order to promote R\&D activities in enterprises. Many more benefits can be achieved through financial cohesion and policies that are supported by the state. The university can contribute with its knowledge and the company can develop new products and services. This network can facilitate the exchange of knowledge that contributes to develop innovation activities. This model, called Triple 
Helix, has been very popular in Western countries by promoting innovation and growth (Castillo, 2010).

Patent SMEs have shown high sensitivity to perceived innovation barriers. This is possibly because of high costs and rigorous requirements involved in registering an invention. In Ecuador, this procedure costs approximately US $\$ 1,500$, and an annual fee of US $\$ 1,000$ is required for a period of 20 years (Ecuadorian Institute of Industrial Property, 2014). Furthermore, the registration procedure may take between three to seven years because the SENADI National Intellectual Rights Service must conduct a detailed study of the required conditions of the patent. It is essential to carry out an improved process to reduce costs and to generate agility to facilitate the execution of the procedures. This process will motivate innovators to patent their creations. On the other hand, companies that develop organizational innovation have shown high sensitivity to barriers because this strategy has global implications for the company. Therefore, innovation needs support from qualified human talent and sufficient financial resources.

The findings of this study show that Ecuadorian SMEs are more susceptible to cost- and knowledge-related barriers that is mainly due to economic constraints and a lack of qualified staff to perform innovation projects. These barriers decrease their competitiveness and impede their development and organizational growth (Hadjimanolis, 1999). In general, the results of this study make the following contributions: First, it generates an information baseline of the SMEs innovation situation. This information will enable public policy formulation. Second, the successful use of a logistic regression with panel data has shown that it is the best method for contrasting dichotomous variables and for eliminating unobserved heterogeneity. Third, this study extends the limited literature on innovation barriers in developing countries such as the Ecuador.

Like many studies, this one has certain limitations. For example, the total sample focuses only on four industrial sectors that restricts the analysis and comparison of other representative segments of Ecuador's economy. Moreover, the studied sample is based on small and medium-sized enterprises but excludes large and micro-enterprises that limits the integrated information of Ecuador's business network. These limitations allow new lines of research that could use a larger study sample in order to compare the obtained results with different economic sectors. Additionally, the variable age can be applied in different strata to understand the effect of the innovation barriers on different lifecycles of the company like in Pellegrino (2018).

\section{Conclusions and recommendations}

Small and medium-sized enterprises are essential to the development of the Ecuadorian economy due to their high degree of representativeness and the significant contribution to the employment generation. So, as innovation is a fundamental element for SMEs, it can produce competitive advantages that provide a prominent market position. The results obtained in this study are the starting point for establishing public policies.

These policies should focus mainly on innovation, especially in small and young companies, by providing government support that enables them to achieve sustainable development and maintain their long-term survival. It is relevant that these findings can 
be used by developing economies to make decisions and create appropriate strategies for the innovation and growth of companies.

Finally, this research can contribute to establishing a public policy of science, technology, and innovation that promotes an innovative culture. It is essential for nations seeking to expand their markets, create skilled jobs, increase workers' incomes, and to improve the quality of life of citizens (MCTIC, 2016).

\section{References}

Aguilar, E., \& Fong, R. (2014). El tamaño empresarial como factor que influye en el comportamiento innovador de las empresas mexicanas: un caso de estudio. Forum Empresarial, 19(2), 31-49.

Alfaro, S., \& Caneo, W. (2014). Obstáculos a la innovación en las pequeñas y medianas empresas (Pymes). (Tesis de pregrado), Universidad de Chile, Chile.

Balarezo, M., \& Ortega, F. (2018). Efecto de la cooperación en actividades de innovación sobre la inversión en innovación y el desempeño innovador de las empresas del Ecuador. Evidencia empírica 2012-2014. (Tesis de pregrado), Universidad de Cuenca, Ecuador.

Banco Central del Ecuador. (2016). Evolución del volumen de crédito y tasas de interés del sistema financiero nacional. Obtenido de https://contenido.bce.fin.ec/documentos/Estadisticas/SectorMonFin/BoletinTasasIntere s/ect201612.pdf

Banco Central Europeo. (2017). Informe Anual. 1-241. Obtenido de https://www.ecb.europa.eu/pub/pdf/annrep/ecb.ar2017.es.pdf

Božić, L., \& Rajh, E. (2016). The factors constraining innovation performance of SMEs in Croatia. Economic Research-Ekonomska Istraživanja, 29(1), 314-324. https://doi.org/10.1080/1331677X.2016.1168040

Camargo, A. (2008). La innovación de tipo Organizacional en las empresas manufactureras de Cartagena de Indias. Semestre Económico, 11(22), 185-202.

Castillo, C. (2010). El modelo de la triple hélice como un medio para la vinculación entre la universidad y empresa. Revista Nacional de administración, 1(1), 85-94.

CEPAL. (2016). Ciencia, tecnología e innovación en la economía digital: la situación de América Latina y el Caribe. 1-95.

Coad, A., Holm, R., Krafft, J., \& Quatraro, F. (2018). Firm age and performance. Journal of Evolutionary Economics, 28(1), 1-11.

Coad, A., Pellegrino, G., \& Savona, M. (2016). Barriers to innovation and firm productivity. Economics of Innovation and New Technology, 25(3), 321-334.

Corchuelo, B., \& Carvalho, A. (2013). Obstáculos a la innovación y políticas públicas de apoyo a la innovación: estudio para las empresas extremeñas. Atas da "XI Jornadas Internacionales de Política Económica", 30, 1-46.

Corchuelo, B., \& Mesías, F. (2015). Percepción de obstáculos a la innovación y propensión a innovar de las empresas en Extremadura. 1-28. 
Das, P., Verburg, R., Verbraeck, A., \& Bonebakker, L. (2018). Barriers to innovation within large financial services firms: An in-depth study into disruptive and radical innovation projects at a bank. European Journal of Innovation Management, 21(1), 96112. https://doi.org/10.1108/EJIM-03-2017-0028

D'Este, P., lammarino, S., Savona, M., \& von Tunzelmann, N. (2012). What hampers innovation? Revealed barriers versus deterring barriers. Research Policy, 41(2), 482488. Retrieved

from https://econpapers.repec.org/article/eeerespol/v_3a41_3ay_3a2012_3ai_3a2_3ap_3a4 82-488.htm

D'Este, P., Rentocchini, F., \& Vega-Jurado, J. (2014). The Role of Human Capital in Lowering the Barriers to Engaging in Innovation: Evidence from the Spanish Innovation Survey. Industry and Innovation, 21(1), 1-19. https://doi.org/10.1080/13662716.2014.879252

De la Corte, J. (2015). Schumpeter y la destrucción de instituciones por los innovadores. (Tesis de pregrado), Universidad Pontificia ICAI ICADE Comillas, España.

El Comercio. (2016). Más patentes se solicitan, pero se innova poco. Obtenido de https://www.elcomercio.com/actualidad/patentes-ecuador-innovacioninvestigacion.html

Erazo, M. (2018). Análisis situacional de la innovación empresarial en el Ecuador. (Tesis de maestría), Universidad Andina Simón Bolívar, Ecuador.

EUROSTAT, \& Nås, S. O. (2011). The Third Community Innovation Survey. 11.

Figueroa, R. (2013). Los clásicos-Joseph Schumpeter y su influencia en la economía del cambio tecnológico. Debate Económico, 2(5), 142-161.

García, M., \& López, A. (2010). Determinants of abandoning innovative activities: evidence from Spanish Firms. Cuadernos de Economía y Dirección de la Empresa, 13(45), 69-91.

Gonzáles, R. (2017). La innovación schumpeteriana y los padres de la Sociología Económica moderna. XI Congreso Español de Sociología, 1-26.

Gupta, H., \& Barua, M. K. (2018). A framework to overcome barriers to green innovation in SMEs using BWM and Fuzzy TOPSIS. Science of the Total Environment, 633, 122139. https://doi.org/10.1016/j.scitotenv.2018.03.173

Hadjimanolis, A. (1999). Barriers to innovation for SMEs in a small less developed country (Cyprus). Technovation, 19(9), 561-570.

Hartono, A., \& Kusumawardhani, R. (2019). Innovation barriers and their impact on innovation: Evidence from Indonesian manufacturing firms. Global Business Review. doi:10.1177/0972150918801647

Heredia Pérez, J. A., Geldes, C., Kunc, M. H., \& Flores, A. (2019). New approach to the innovation process in emerging economies: The manufacturing sector case in Chile and Peru. Technovation, 79, 35-55. https://doi.org/10.1016/j.technovation.2018.02.012

Hossain, M. (2016, September). Business Model Innovation: Past Research, Current Debates, and Future Directions. https://doi.org/10.2139/ssrn.2836439

How, B. S., Ngan, S. L., Hong, B. H., Lam, H. L., Ng, W. P. Q., Yusup, S., ... Rambli, J. (2019). An outlook of Malaysian biomass industry commercialization: Perspectives and challenges. Renewable and Sustainable Energy Reviews, 113, 109277. https://doi.org/10.1016/j.rser.2019.109277 
lammarino, S., Sanna Randaccio, F., \& Savona, M. (2009). The perception of obstacles to innovation. Foreign multinationals and domestic firms in Italy. Revue d'economie industriella, 125, 75-104.

INEC. (2013). Catálogo de Estadísticas y Servicios. 1-24. Obtenido de http://www.ecuadorencifras.gob.ec/catalogo-inec-2013-2/

INEC. (2014). Encuesta Nacional de Actividades de Ciencia, Tecnología e InnovaciónACTI. Obtenido de http://www.ecuadorencifras.gob.ec/encuesta-nacional-deactividades-de-ciencia-tecnologia-e-innovacion-acti/

Instituto Ecuatoriano de Propiedad Industrial. (2016). Obtenido de https://www.propiedadintelectual.gob.ec/patentes/

Instituto Nacional de Propiedad Industrial. (2014). Tasas justas para un comercio más justo. Obtenido de Recuperado de https://www.propiedadintelectual.gob.ec/tasas/

Kuppig, V. D., Cook, Y. C., Carter, D. A., Larson, N. J., Williams, R. E., \& Dvorak, B. I. (2016). Implementation of sustainability improvements at the facility level: Motivations and barriers. Journal of Cleaner Production, 139, 1529-1538. https://doi.org/10.1016/j.jclepro.2016.08.167

Leal-Rodríguez, A. L., Eldridge, S., Roldán, J. L., Leal-Millán, A. G., \& Ortega-Gutiérrez, J. (2015). Organizational unlearning, innovation outcomes, and performance: The moderating effect of firm size. Journal of Business Research, 68(4), 803-809. https://doi.org/10.1016/j.jbusres.2014.11.032

Lesáková, L'. (2014). Evaluating Innovations in Small and Medium Enterprises in Slovakia. Procedia - Social and Behavioral Sciences, 110, 74-81. https://doi.org/10.1016/j.sbspro.2013.12.849

Lesáková, L'., Gundová, P., Král', P., \& Ondrušová, A. (2017). Innovation Leaders, Modest Innovators and Non-innovative SMEs in Slovakia: Key Factors and Barriers of Innovation Activity. Organizacija, 50(4), 325-338. https://doi.org/10.1515/orga-20170024

Mayorga, M., \& Muñoz, E. (2000). La técnica de datos de panel una guía para su uso e interpretación. Banco Central de Costa Rica. Departamento de investigaciones económicas, 1-4.

Mclaughlin, S. (2011, June 6). Profiling Factors that Impact Innovation Capability in UK Service Industry SMEs. https://doi.org/10.13140/RG.2.1.4101.5763

MCTIC. (2016). Estratégia Nacional de Ciência, Tecnologia e Inovação 20162022. Retrieved from http://www.finep.gov.br/images/afinep/Politica/16_03_2018_Estrategia_Nacional_de_Ciencia_Tecnologia_e_Inovacao_ 2016_2022.pdf

Monsalvez, C. (2017). Características, obstáculos y efectos de la innovación en empresas del sector maderero de la región del Maule. 38(1), 89-95.

Morales, E. (2012). Barreras Financieras de las Empresas Innovadoras Españolas. Accenture, 1-35. Obtenido de https://www.uam.es/docencia/degin/catedra/documentos/9_Barreras_financie ras_de_las_empresas_innovadoras_espanolas.pdf

OECD. (2018, October 22). Oslo Manual 2018-Guidelines for Collecting, Reporting and Using Data on Innovation, 4th Edition-En-OECD. Retrieved November 5, 2019, from https://www.oecd.org/science/oslo-manual-2018-9789264304604-en.htm 
Olaya, E. (2018). Efecto del gasto en investigación y desarrollo en el ingreso de los establecimientos de Ecuador. Revista Económica, 3(1), 7-18.

Pachouri, A., \& Sharma, S. (2016). Barriers to Innovation in Indian Small and MediumSized Enterprises (SSRN Scholarly Paper No. ID 2838109). Retrieved from Social Science Research Network website: https://papers.ssrn.com/abstract=2838109

Pellegrino, G. (2018). Barriers to innovation in young and mature firms. Journal of Evolutionary Economics, 28(1), 181-206.

Piater, A. (1984). Barriers to innovation (Primera ed.). Londres, Reino Unido: Pinter Pub Ltd.

Pino, C., Felzensztein, C., Zwerg-Villegas, A. M., \& Arias-Bolzmann, L. (2016). Nontechnological innovations: Market performance of exporting firms in South America. Journal of Business Research, 69(10), 4385-4393. https://doi.org/10.1016/j.jbusres.2016.03.061

Portillo, P., Scarpellini, S., \& Marín, L. (2015). Barreras y drivers para la eco-innovación en las pymes españolas: estructura financiera y organización. In Actas del XVIII Congreso AECA. Obtenido de http://www. aeca1. org/xviiicongresoaeca/cd/59c. pdf.

Ramírez, O., \& Sebastián, N. (2015). Evaluación de las pymes del sector de producción de muebles para las construcciones en el Distrito Metropolitano de Quito y diseño de estrategias para mejorar su productividad. Periodo 2010-2012. (Tesis de pregrado), Pontificia Universidad Católica del Ecuador, Ecuador.

Segarra, A., García, J., \& Teruel, M. (2008). Barriers to innovation a public policy in Catalonia. International entrepreneurship and management journal, 4(4), 431-451.

Seidel-Sterzik, H., McLaren, S., \& Garnevska, E. (2018). Effective Life Cycle Management in SMEs: Use of a Sector-Based Approach to Overcome Barriers. Sustainability, 10(2), 359. https://doi.org/10.3390/su10020359

Silvestre, D., \& Rodríguez, J. (2018). Análisis de los obstáculos a los cuatro tipos de innovación tecnológica: caso de los establecimientos en el sector de servicios en Colombia: Aproximación teórica desde el Manual de Oslo con aplicaciones en la $\mathrm{V}$ Encuesta de Innovación y Desarrollo. (Tesis de pregrado), Universidad de La Sabana, Colombia.

SRI. (2015). Grupos Económicos. Obtenido de http://www.sri.gob.ec/web/guest/gruposeconomicos 1

Strobel, N., \& Kratzer, J. (2016). Obstacles to Innovation for SMEs: Evidence from Germany. International Journal of Innovation Management, 21(03), 1750030. https://doi.org/10.1142/S136391961750030X

Superintendencia de Compañías. (2015). Ranking Empresarial. Obtenido de https://appscvs.supercias.gob.ec/rankingCias/

Tello Cabello, S. (2014). Importancia de la micro, pequeñas y medianas empresas en el desarrollo del país. Lex, 12(14), 199-218.

Tiwari, R., \& Buse, S. (2007). Barriers to innovation in SMEs: Can the internationalization of R\&D mitigate their effects? Working Paper (50), 8-9.

Toomsalu, L., Tolmacheva, S., Vlasov, A., \& Chernova, V. (2019). Determinants of innovations in small and medium enterprises: a European and international experience. Terra Economicus, 17(2). https://doi.org/10.23683/2073-6606-2019-17-2-112-123 
Türkeș, M. C., Oncioiu, I., Aslam, H. D., Marin-Pantelescu, A., Topor, D. I., \& Căpuşneanu, S. I. (2019). Drivers and Barriers in Using Industry 4.0: A Perspective of SMEs in Romania. https://doi.org/10.3390/pr7030153

Ucedo, H. (2013). Comparación de los modelos logit y probit del análisis multinivel, en el estudio del rendimiento escolar. Universidad Nacional Mayor de San Marcos. Obtenido http://cybertesis.unmsm.edu.pe/bitstream/handle/cybertesis/3703/Ucedo_sv.pdf?seque nce $=1 \&$ isAllowed $=y$

Udagedara, R. S., \& Allman, K. (2017). Organizational Dynamics and Adoption of Innovations: A Study within the Context of Software Firms in Sri Lanka: Journal of Small Business Management. Journal of Small Business Management, 57(2), 450-475. https://doi.org/10.1111/jsbm.12378

Xiaobao, P., Wei, S., \& Yuzhen, D. (2013). Framework of open innovation in SMEs in an emerging economy: Firm characteristics, network openness, and network information. International Journal of Technology Management, 62(2/3/4), 223. https://doi.org/10.1504/IJTM.2013.055142

Yu, X., Yan, J., \& Assimakopoulos, D. (2015). Case analysis of imitative innovation in Chinese manufacturing SMEs: Products, features, barriers and competences for transition. International Journal of Information Management, 35(4), 520-525. https://doi.org/10.1016/j.ijinfomgt.2015.03.003

Zamora, G., \& Villamar, X. (2011). Caracterización de la PYME en la Industria Manufacturera del Distrito Metropolitano de Quito. (Tesis de pregrado), Pontificia Universidad Católica del Ecuador, Ecuador.

Zapata, M., Nieves, M., \& Alzate, B. (2014). Gestión de la Innovación en Pequeñas y Medianas Empresas. Generando ventajas competitivas y posicionamiento en el Mercado. Gestión de las Personas y Tecnología, 19, 34-39.

Zhu, Y., Wittmann, X., \& Peng, W. (2012). Institution-based barriers to innovation in SMEs in China. Asia Pacific Journal of Management, 29(4), 1131-1142. 